\title{
THE ACCOUNTING PRINCIPLES BOARD AND DIFFERENCES AND INCONSISTENCIES IN ACCOUNTING PRACTICE: AN INTERIM APPRAISAL
}

\author{
Robert T. Sprouse* and DetLev F. Vagts $\dagger$
}

The Accounting Principles Board has, since its creation in 1959, existed as an operating organization for almost precisely six years at the time of this writing. This seems, then, an appropriate point at which to make an interim appraisal of its performance. This article begins with an introductory section explaining the structure and procedure of the Board and the targets set for it. It then proceeds to a description and analysis of the pronouncements thus far made by the Board. Finally it takes up the task of appraising the Board's success in meeting its goals.

A fair appraisal of the Board's performance should consider, among other things, the adequacy of the Board's organization and procedures to its mission. It must take into account the extent to which its operations were influenced by exogenous constraints in the environment of the accounting profession; perhaps its progress or lack of progress was beyond its control. The accounting profession and the Board are both relatively young. Accordingly, it was our thought that one might draw on the experience of the legal profession with institutions intended to render the law more uniform, and (to borrow a phrase from the Board's stated objectives) "to lead in the thinking on unsettled and controversial issues." Recognizing that significant differences exist between the two situations, we nonetheless felt that a careful comparison would afford a perspective on the situation. It may also make it easier for the lawyer-reader to understand the problems of the accounting profession.

\section{I}

The Board: Structure, Authority, and Goals

To analyze the performance of the Board requires some understanding of the environment in which it operates, the authority given to it, the procedures that it uses, and the targets set for it.

\section{A. Structure and Procedure}

The American Institute of Certified Public Accountants (AICPA) is the major professional organization for those engaged in performing independent audits of

* B.A. I95I, San Diego State College; M.B.A. I952, Ph.D. 1956, University of Minnesota. Professor of Accounting, Graduate School of Business, Stanford University.

† A.B. I948, LL.B. I951, Harvard University. Professor of Law, Harvard University. 
the accounts of business firms-particularly of publicly held corporations-as a basis for rendering opinions as to whether such firms' financial statements present fairly their financial position and results of operations "in conformity with generally accepted accounting principles." The AICPA is administered by an Executive Committee; the main legislative body of the AICPA is the Council, made up of representatives from all parts of the United States. Certain matters, such as amendments to the Code of Professional Ethics, are submitted to a vote of the entire membership.

Prior to 1959 there existed a Committee on Accounting Procedure, created in $193^{8}$ by the American Institute of Accountants (as the AICPA was then called) to deal with accounting matters. Before that there had been some significant discussions and correspondence with the New York Stock Exchange, ${ }^{2}$ and in 1934 six accounting rules were adopted directly by vote of the membership, ${ }^{3}$ but there was no continuing systematic procedure for the establishment of accounting principles. During the twenty years of its existence, the Committee on Accounting Procedure published fifty-one Accounting Research Bulletins ${ }^{4}$ as part of a program of research and publication of recommendations about the use of certain accounting procedures. The Bulletins tended to present ad hoc solutions to unrelated specific problems and frequently recognized the acceptability of two or more procedures for accounting for identical transactions occurring under identical circumstances. Furthermore, the Bulletins presented recommendations only; with the exception of the six rules adopted by the AICPA membership vote, the conclusions contained in the Bulletins were not binding on the Institute membership. Accordingly, procedures not embraced in the Bulletins might also be considered to be "generally accepted." Dissatisfaction with this approach led to a report of the Special Committee on Research Program to the Council of the AICPA which was approved in April I959. ${ }^{5}$ With this approval was established the Accounting Principles Board (APB), composed at first of eighteen, and then of twenty-one, members. These are largely accountants

\footnotetext{
${ }^{2}$ The standard 'short-form report of the auditor which is customarily used in connection with the basic financial statements contains a "scope paragraph," indicating the extent of the auditing work performed, and an "opinion paragraph," indicating whether in the auditor's opinion the financial statements provide fair presentations "in conformity with generally accepted accounting principles" and whether such accounting principles have been "applied on a basis consistent with that of the preceding year." See Committee on Auditing Procedure, AICPA, Auditing Standards and Procedures ch. io (Statement on Auditing Procedure No. 33, x963).

${ }^{2}$ Memoirs and Accounting Thought of George O. May ch. 6 (Paul Grady ed. 1962); American Institute of Accountants, Audits of Corporate Accounts (I934).

${ }^{3}$ Commirtee on Accounting Procedure, AICPA, Restatement and Revision of Accounting Research Bulletins if (Accounting Research Bull. No. 43, r953).

"Bulletins Nos. I through 42 were restated in Comimittee on Accounting Procedure, AICPA, Restatemient and Revision of Accounting Research Bulletins (Accounting Research Bull. No. 43, 1953), and Commitree on TrRminologr, AICPA, Review and RÉsumé (Accounting Terminology Bull. No. I, 1953). Accounting Research Bulletins Nos. 43 through 5I, and Accounting Terminology Bulletins Nos. $x$ through 4 have been reproduced in Accounting Research and Terminology Bulletins (final ed. $196 \mathrm{r}$ ).

J. Accountancy, June r959, p. 7 .
} 
in active practice. Characteristically, each of the "big eight" accounting firms is represented; the rest of the seats are distributed among representatives of smaller firms plus a few members from business firms, the academic community and government. $^{6}$ The Board promptly adopted "Charter Rules" to detail its procedures and objectives. ${ }^{7}$

There was established a Division of Accounting Research with a permanent professional staff to undertake the more thoroughgoing research considered necessary in order for the Board to accomplish its objectives. It was contemplated that matters to be considered by the Board would first be studied by an individual or group of individuals on the Research Staff. A small project advisory committee, chaired by a member of the Board, would be available to the researcher for consultation. The subjects being investigated were to be announced publicly so that interested parties could submit their views. When the accounting research study was completed the result was to be submitted to the APB and published for the information of members of the profession and other interested parties. After deliberation, the Board was to prepare and circulate an "exposure draft" of its conclusions and recommendations, soliciting comments. Finally, the "exposure draft" was to be revised and the opinion or other publication, which was to carry the approval of at least two-thirds of the members of the Board, was to be published.

\section{B. Authority of Board Actions}

The status of Board pronouncements was not at first made clear; presumably they had only the status previously given to opinions of the Committee on Accounting Procedure. In April 1963, following the publication of an opinion on accounting for the investment credit and the resulting controversy in the profession, the history of which is recounted below, ${ }^{8}$ the Board considered a proposal that its opinions be deemed to constitute generally accepted accounting principles. The Board rejected that proposal but in June 1963 voted eleven to eight to recommend a less stringent measure to the Executive Committee of the AICPA. The Board proposed that members of the Institute be required "to direct attention to any material variation between the accounting principles followed and principles which the Board has approved" and that "in addition to the obligation of members to report departures from generally accepted accounting principles they ... be required to include a report as to departures from opinions of the Accounting Principles Board."

\footnotetext{
"The auditing profession and the "big eight" certified public accounting firms that dominate the profession are well described in Wise, The Auditors Have Arrived, Fortune, Nov. 1960, pp. 151-57, I86-98, and id., Dec. I960, pp. r44-48, 239-44.

Taicpa, Organization and Operation of the Accounting Resenrch Program and Related acTIVITIEs (I959) (unpublished). With only slight modification the substance of the Charter Rules follows Spectal Comm. on Research Program, Aicpa, Report to Council (1958), reprinted in J. Accountancy, Dec. $x 958$, p. 62 .

${ }^{8}$ See text accompanying notes $25-30$ infra.

- Executive Comm., Aicpa, Status of Pronouncements of Accounting Principles Bonkd 8 (Special Report, I964).
} 
The Executive Committee rejected the Board's proposal on the ground that it established two sets of standards-generally accepted accounting principles and opinions of the APB-and thereby created an undesirable distinction between the two. Instead, the Executive Committee adopted a proposal similar to the one considered and rejected by the Board in April. The Executive Committee's proposal, adopted by a vote of eight to three, was then submitted to the Council. The matter was put before the Council at its October I963 meeting, but, in introducing it, the Executive Committee suggested that action not be taken until there had been adequate opportunity to consider and debate the issues. The matter was debated by the Council in the spring of 1964 , at which time a vote was deferred pending study of the implementation of a compromise proposal..$^{10}$ In October 1964 , the Council unanimously adopted a set of recommendations, among which the following are particularly relevant:

"Generally accepted accounting principles" are those principles which have substantial authoritative support.

Opinions of the Accounting Principles Board constitute "substantial authoritative support."

"Substantial authoritative support" can exist for accounting principles that differ from opinions of the Accounting Principles Board.

If an accounting principle that differs materially in its effect from one accepted in an Opinion of the Accounting Principles Board is applied in financial statements, the reporting member must decide whether the principle has substantial authoritative support and is applicable in the circumstances.

If he concludes that it does not, he would either qualify his opinion, disclaim an opinion, or give an adverse opinion as appropriate.

If he concludes that it does have substantial authoritative support: (I) he would give an unqualified opinion and (2) disclose the fact of departure from the Opinion in a separate paragraph in his report or see that it is disclosed in a footnote to the financial statements and, where practicable, its effect on the financial statements. ${ }^{11}$

Although this means that APB opinions need not necessarily be followed, the disclosures required when they are not followed provide a deterrent to extensive deviations. The Council's action gives a status to APB opinions not previously held by Institute committee pronouncements.

\section{Board Goals}

The goals towards which the Board is to work can be found in the report of the Special Committee on Research Program and in the "Charter Rules" of the Board itself.

At the outset, the Charter Rules state certain "basic considerations" underlying

\footnotetext{
${ }^{10} \mathrm{~J}$. Accountancy, June 1964, p. 9.

11 AICPA, Disclosure of Departures from Opinions of the Accounting Principles Board (Special Bull., 1964).
} 
the Institute's research program and related activities in which the Board plays the leading role. From these "basic considerations" the following interrelated but separable objectives can be extracted:

(I) to advance the written expression of what constitutes generally accepted accounting principles;

(2) to determine appropriate practice and to narrow the areas of difference and inconsistency in practice; and

(3) to lead in the thinking on unsettled and controversial issues.

Also contained in the Charter Rules, as well as in the Report of the Special Committee on Research Program, is a specific charge:

As soon as practicable after its organization the [Accounting Research] Division shall undertake a study of the basic postulates underlying accounting principles generally, and the preparation of a brief statement thereof. It also shall undertake a study of the broad principles of accounting, and the preparation of a reasonably condensed statement thereof. The results of these, as adopted by the [Accounting Principles] Board, shall serve as the foundation for the entire body of subsequent pronouncements by the Institute on accounting matters, to which each new release shall be related.

The specific charge to prepare a statement of the basic postulates and a statement of the broad principles of accounting is directly related to the first objective stated above-a written expression of what constitutes generally accepted accounting principles. For more than thirty years, auditors have been formalizing their opinions about the financial statements they examine in terms of those statements' conformity to "accepted principles of accounting" and "generally accepted principles of accounting."12 Such principles, however, have never been endowed with much precision. Considerable uncertainty even prevails about the nature of an accounting principleparticularly with respect to the distinction between an accounting principle itself and an accounting procedure which represents an application of an accounting principle. The only authoritative guidance that has been available has been of a very general nature, such as that provided in Generally Accepted Auditing Standards, a special report by the Committee on Auditing Procedure published by the AICPA:

The determination of whether "generally accepted accounting principles" have been adhered to requires the exercise of judgment on the part of the independent certified public accountant, as well as knowledge as to what principles have found general acceptance even though certain of these in manner of application may have received only limited usage. An accounting principle may be found to have only limited usage but still have general acceptance. . . .

In addition to this matter of an accounting principle's being generally accepted even if not generally followed, it is necessary also to bear in mind that there may be

${ }^{12}$ Reed K. Storey, The Senrch for Accounting Principles $1 x, 26$ (xg64). 
a considerable diversity of practices between different concerns in the application of an accounting principle.... Thus, while one concern may follow an accounting procedure distinctly peculiar to itself, this in no way disqualifies it from being accorded a recognition of following "generally accepted accounting principles," if the broad principle which that procedure seeks to implement is, in fact, a generally accepted one. ${ }^{13}$

The fifty-one Accounting Research Bulletins issued by the Institute's former Committee on Accounting Procedure dealt with specific accounting issues, but each bore the caution that the bulletins merely represent "the considered opinion of at least two-thirds of the members of the committee" and that "the authority of the bulletins rests upon the general acceptability of opinions so reached."

Recently, an eminent accounting authority equated "generally accepted accounting principles" with "accounting practices which have substantial authority back of them" and identified "the sources for determining whether an accounting practice has substantial authoritative support" as follows: (I) "practices commonly found in business"; (2) "requirements and views of stock exchanges [and] . . commercial and investment bankers"; (3) "regulatory commissions' uniform systems of accounts and accounting rulings," although "the commissions sometimes depart from generally accepted accounting principles"; (4) regulations and accounting releases of the SECregulations and opinions which "to date are entitled to acceptance by their merit as well as on the basis of the statutory authority of the Commission"; (5) "affirmative opinions of practicing and academic certified public accountants ... found in oral or written opinions, expert testimony, textbooks and articles"; and (6) "published opinions by committees of the American Accounting Association and of the American Institute of CPAs."14 With such resources, it seems unlikely that any accounting practice would lack some authoritative support; the auditor's judgment, therefore, presumably focuses on whether whatever authoritative support that can be mustered is substantial.

Under these circumstances, it is readily understandable why priority should have been assigned to a study of the basic postulates underlying accounting principles generally and a study of the broad principles of accounting and the preparation of concise statements of each to use as the foundation for subsequent pronouncements. Such a study indeed appears to be an essential step in furthering the objectives of advancing the written expression of what constitutes generally accepted accounting principles, narrowing the areas of difference and inconsistency in practice, and leading in the thinking on unsettled and controversial issues.

\footnotetext{
${ }^{13}$ Committee on Auditing Procedure, Aicpa, Generally Accepted Auditing Standards-Their Significance AND Scope 50 (r954). (Emphasis added.)

1\& Paul Grady, Inventory of Generally Accepted Accounting Principles for Business EnterPRISES 52-53 (AICPA Accounting Research Study No. 7, 1965). Mr. Grady was AICPA Director of Accounting Research during most of the period that Accounting Research Study No. 7 was in progress.
} 


\section{Actrons to Date}

\section{A. Actions Under the Specific Charge}

During the Accounting Principles Board's initial year of operation, six accounting research studies were launched, including the two specifically called for by the Charter Rules-a study of the basic postulates underlying accounting principles generally and a study of the broad principles of accounting. ${ }^{15}$

Accounting Research Study No. I, The Basic Postulates of Accounting, was completed and published in September Ig6r. ${ }^{18}$ The related study of accounting principles, entitled A Tentative Set of Broad Accounting Principles for Busincss Enterprises, was published in April $1962 .{ }^{17}$ The Board then reacted promptly:

The Board feels that there is ample room for improvement in present generally accepted accounting principles and a need to narrow or eliminate areas of difference which now exist. Accounting principles and practices should be adapted to meet changing times and conditions, and, therefore, there should be experimentation with new principles and new forms of reporting to meet these conditions. The Board believes, however, that while these studies are a valuable contribution to accounting thinking, they are too radically different from present generally accepted accounting principles for acceptance at this time.

After a period of exposure and consideration, some of the specific recommendations in these studies may prove acceptable to the Board while others may not. The Board therefore will await the results of this exposure and consideration before taking further action on these studies..$^{18}$

The comment of Andrew Barr, Chief Accountant of the Securities and Exchange Commission, who served as a member of the project advisory committee appointed to consult with the research staff, pinpointed the primary difficulty: "This "Tentative Set of Broad Accounting Principles for Business Enterprises' must be recognized as a statement of what the authors believe generally accepted accounting principles should be rather than what they are today."19 The researchers had taken their cue from the statement contained in the Charter Rules that "something more than a survey of existing practice" was envisaged. The majority of the Board took a different view in shelving the two studies. Because of the difference in approaches, the initially mandated focus of activity on dealing with areas of difference and inconsistency in practice through attention to fundamentals-that is, concepts, postulates and principles-appeared to have been dissipated.

In commenting upon the research study of broad accounting principles, Paul

\footnotetext{
${ }^{26} \mathrm{~J}$. Accountancy, April I96o, p. 9.

${ }^{10}$ Maurice Moonitz, The Basic Postulates of Accounting (AICPA Accounting Rescarch Study No. $x, 196 x$ ).

${ }^{17}$ Robert T. Sprouse \& Maurice Moonitz, A Tentative Set of Broad Accounting Principles for Business Enterprises (AICPA Accounting Research Study No. 3, 1962).

${ }^{18} \mathrm{~J}$. Accountancy, May 1962, pp. 9-ro.

${ }^{10}$ Sprouse \& Moonitz, op. cit. stupra note 17 , at 60 .
} 
Grady, retired partner of Price Waterhouse \& Co. and member of the project advisory committee, suggested that "there would be great merit in having a brief summary of generally accepted accounting principles for business enterprises as of the present time" and submitted "such a suggested summary."20 When, after serving three years as Director of Accounting Research, Professor Maurice Moonitz returned to his academic post, Mr. Grady agreed to succeed him for the express purpose of preparing an "inventory" of those accounting principles currently considered to be generally accepted. ${ }^{21}$ His Inventory of Generally Accepted Accounting Principles for Business Enterprises was completed and published in March $1965 .{ }^{22}$

In announcing the commissioning of the Inventory in July I963, the Board referred to it as an "extension" of the original research program. "By 'inventorying" principles and procedures now in general use, and by exposing them to all interested parties for comment, the Board believes that areas of agreement and disagreement can be isolated, which will serve as useful guides to current action and to further research efforts." At the same time, the Board announced its intention to resume the work of the defunct Committee on Accounting Procedure in publishing opinions "as to preferred accounting treatments of specific types of transactions." The development of "a logical and consistent statement of basic postulates and broad principles of accounting from which rules or guides applicable to specific situations may be readily derived" was explicitly reclassified as a long-range parallel objective. ${ }^{23}$

At this point of time the specific charge contained in the Charter Rules has apparently been deferred indefinitely, if not abandoned completely. To the date of this writing the Board has made no further announcement suggesting whether or how the results of the Inventory may be used to narrow the areas of difference and inconsistency in practice. The Board's failure to tackle the specific charge directly seriously diminishes the likelihood of any substantial progress toward the objective of narrowing the areas of difference and inconsistency in practice in the foreseeable future. However, the Board has been soliciting voluntary cooperation among certain industry groups to eliminate "unnecessary variations in accounting for similar transactions by companies in the same industry." Certainly this latter endeavor is a step in the direction of their stated objectives. Unfortunately, the scope of this approach is inherently limited.

\section{B. Opinions of the Accounting Principles Board}

While the Board has thus deferred action on the specific charge to deal with basic postulates and principles, it has published six opinions on particular, rather

\footnotetext{
${ }^{20} I d$. at 70 . With the addition of three introductory paragraphs, Grady's complete comments on Accounting Research Study No. 3 also appeared as an article, The Quest for Accounting Principles, J. Accountancy, May I962, p. 45 .

${ }_{21}^{2}$ Powell, Inventory of Generally Accepted Accounting Principles, J. Accountancy, March 1965, p. 30.

${ }^{22}$ GrADY, op. cit. supra note 14. For excerpts therefrom, see Appendices $C$ and $D$ at the end of this symposium.

${ }^{23}$ J. Accountancy, Aug. 1963, pp. 13-14.

34Id. at I4.
} 
narrow, accounting questions. As was the case with the series of Accounting Research Bulletins issued during 1939-59, the APB opinions have been concerned primarily with the application to specific accounting problems of accounting concepts and principles that have never been clearly established; none of the opinions purports to establish fundamentals that will be relied upon in reaching later opinions.

\section{The Depreciation and Investment Credit Opinions}

Changes in the Internal Revenue Code and in its application, made during 1962, prompted the Board to issue two opinions. The first ${ }^{25}$ was issued in November rg62-some six months following the rejection of the research studies of basic postulates and broad principles. This opinion merely acknowledged the introduction of "new depreciation guidelines and rules" for income tax purposes and called for continued conformity with the earlier recommendations of the Committee on Accounting Procedure with respect to depreciation estimates and accounting for income taxes as the new guidelines and rules were adopted. The 1962 changes in the administration of the Internal Revenue Code had simply introduced a new variation of an old accounting problem. The Board's action with respect to this matter was almost superfluous, but it clearly fell within its objective of determining appropriate practice and leading in the thinking on unsettled issues.

The second opinion ${ }^{26}$ also dealt with what was ostensibly a relatively innocuous matter-accounting for the newly enacted "investment credit." In this case, however, the Board's action touched off a chain of events that has culminated in the most significant accomplishment during the six years of the Board's existence--the adoption of the requirement that departures from APB opinions be disclosed. This is an accomplishment for which the Board cannot be given full credit but nevertheless an accomplishment in which the Board played a leading role.

This is not the place to debate the merits of the Board's reasoning and recommendations with respect to accounting for the investment credit or with respect to any other accounting matter. We are concerned solely with an evaluation of the Board's performance relative to the stated objectives and initial charge as stated in the Report to the Council and in the Charter Rules. In this regard, there can be no doubt as to the propriety of the Board's action in issuing Opinion No. 2 stating its conclusions with respect to the proper accounting for the investment credit. The investment credit was a clear-cut example of an unsettled and controversial issue; the Board was charged with the responsibility for "leading in the thinking" about such issues and "determining appropriate practice." The task was particularly formidable in view of the absence of an established set of postulates and principles or other standards to which the reasoning and recommendations could be related. The

\footnotetext{
${ }^{25}$ Accounting Principles Board, aICPA, New Depreciation Guidelines and Rules (Opinion No. I, 1962).

${ }^{26}$ Accounting Principles Board, AicPa, Accounting for the "Investment Crepit" (Opinion No. 2, 1962 ).
} 
Board was forced to make recommendations that were directly dependent upon the nature of income, the nature of assets, and the nature of liabilities, but without these concepts ever having been clearly established. The situation was analogous to that which the American Law Institute would confront if it had to decide whether a retraction of an offer was effective if not received by the offeree before he mailed his acceptance if there were no agreed upon concept of "offer" or "acceptance" to rely on or indeed no fixed agreement that offer and acceptance were necessary to the formation of a contract. ${ }^{27}$ In addition, the need for recommendations was urgent. The credit applied to qualified investments made after December 3I, $\mathrm{I} 96 \mathrm{r}$; corporate fiscal years ending in 1962 after the enactment were almost certain to include qualified investments and hence require an accounting for the related investment credit.

Placed in this untenable position, it was noteworthy that the Board was able to muster the required two-thirds majority in support of essentially a single effect on the measurement of income-an achievement essential to the minimization of "difference and inconsistency in practice." The Board's opinion expressly permitted at least three distinct methods of reporting the effect of the investment credit in the balance sheet, but the effect on income was the center of attention; the effect on the balance sheet was clearly secondary. The vote was fourteen to six-the six holding out for the acceptability of both of two distinct alternatives. The majority favored spreading the effect of the investment credit on income over the useful life of the qualified investments; the minority argued that immediate recognition of the effect of the investment credit on income-the so-called flow-through methodshould also be considered acceptable.

The minority had greater strength than the number of votes indicated. The most influential practitioners were evenly split. The representatives of four of the "big eight" certified public accounting firms operating in the United States were among the dissenters; the other four big-eight representatives supported the opinion. ${ }^{28}$ Furthermore, during the time that the Board was considering accounting for the investment credit, the Chief Accountant of the SEC made known a preference for "immediate recognition," and, following the Board's decision, the SEC announced that it would accept either financial statements prepared in accordance with APB Opinion No. 2 or financial statements reflecting immediate recognition of the effect of the investment credit on income, even if certified public accountants qualified their opinions about the latter procedure's conformity with generally accepted ac-

\footnotetext{
${ }^{27}$ Compare the progression from general to specific ideas on this question in Restatement, Contracts $\$ \$ 19,20,22,34,35,41,69$ (1932).

"In addition to representatives from each of the "big eight," the twenty members of the APB voting on Opinion No. 2 included four practitioners from smaller CPA firms, three accounting professors, two industry representatives, an insurance company executive, the U.S. Comptroller General, and the retired AICPA Director of Research. Arthur M. Cannon, the insurance company executive, and Wilbert A. Walker of United States Steel Corporation joined the four "big eight" representatives in dissenting.
} 
counting principles. ${ }^{29}$ Even before the SEC action, however, the dissenting firms were openly considering ignoring the Board's opinion and rendering unqualified opinions on either basis.

The SEC action sapped APB Opinion No. 2 of any strength it might otherwise have had. In fact, the Board's recommendation was generally ignored, with certified public accountants rendering unqualified opinions with respect to financial statements prepared on either the "spreading" or "immediate recognition" basis.

The futility of the Board's attempt to establish a single acceptable procedure for accounting for the investment credit on essentially a voluntary basis without the support of some of the leading members of the profession, and more particularly without the support of the SEC, was publicly acknowledged with the issuance of Opinion No. 4 in March 1964 :

... [T] he authority of the Opinions of this Board rests upon their general acceptability. The Board, in the light of events and developments occurring since the issuance of Opinion No. 2, has determined that its conclusions as there expressed have not attained the degree of acceptability which it believes is necessary to make the Opinion effective.

In the circumstances the Board believes that, while the method of accounting for the investment credit recommended . . . should be considered preferable, the alternative method of treating the credit ... is also acceptable. ${ }^{30}$

The prestigious image enjoyed by the Accounting Principles Board was undoubtedly blemished by its joust with the investment credit. One must note, however, that the difficulties faced by the Board in this matter were to a large extent inherent in any attempt to narrow differences and inconsistencies in practice where no one solution is clearly superior.

\section{Opinions Nos. 3 and 5}

In October 1963 , the Board published Opinion No. 3, The Statement of Source and Application of Funds, and, in September 1964, Opinion No. 5, Reporting of Leases in Financial Statements of Lessee, was issued. These, unlike the three opinions previously discussed, had been developed by the processes contemplated in the Charter Rules.

In Opinion No. 3, the Board concluded that a statement of source and application of funds should be presented as supplementary information in financial reports. But the opinion stated that "the inclusion of such information is not mandatory, and it is optional as to whether it should be covered in the report of the independent accountant." ${ }^{31}$ In view of the fact that the inclusion of such statements in published

\footnotetext{
${ }^{20}$ SEC Accounting Ser. Release No. 96, Jan. 10, 1963.

${ }^{30}$ Accounting Principles Bonrd, AICPA, Accounting for the "Investment Credit" (Opinion No. 4,1964 ) (amending Opinion No. 2).

${ }^{31}$ Accounting Principles Board, AicPa, The Statement of Source and Application of Funds I6 (Opinion No. 3, 1963).
} 
annual reports was already fairly widespread, the position taken by the Board could hardly be characterized as revolutionary. Nevertheless, the opinion attracted the attention of the New York Stock Exchange, whose president sent copies to listed companies together with a letter urging compliance with the Board's recommendations that such statements be included in annual reports and stating a preference that they be covered by the auditor's opinion. ${ }^{32}$

One can reasonably assume, therefore, that the Board's action has caused the number of published funds statements to be increased and probably to be published more conspicuously. Indeed, recently a number of statements of source and application of funds included in annual reports have been covered explicitly by the auditor's opinion. ${ }^{33}$ The effect of the strong position taken by the Board in the opinion in denouncing certain terminology, such as "cash earnings," and certain computations, such as "cash flow per share," is difficult to assess.

The subject of Opinion No. 5, accounting for long-term leases, had originally been dealt with in Accounting Research Bulletin No. 38, published in r949. The position then taken was reiterated in the Restatement and Revision of Accounting Research Bulletins published in 1953. However, with the increasing use of lease arrangements, the subject has continued to be one of the most hotly debated issues in the whole field of financial reporting: should long-term leases be reflected among the assets and liabilities of the lessee or should they be referred to only in footnotes? Strangely enough, this is one accounting matter about which there is virtually complete uniformity in practice-long-term leases are not included among the assets and liabilities of lessees. ${ }^{34}$ There has been considerable variation in the nature and extent of the information provided in footnotes, but the primary issue was as stated above.

The Accounting Research Study on leases that preceded the Board's opinion contained recommendations calling for extensive inclusion of leases among assets and liabilities; APB Opinion No. 5 was basically consistent with the previous Institute pronouncements on the subject in relying primarily on footnote disclosures. The opinion was, however, much more explicit as to the nature and extent of those disclosures. The opinion also outlined circumstances that "tend to indicate" that a lease arrangement is in substance a purchase and therefore should be reflected among the lessee's assets and liabilities. Typically, however, lessees do not want their reported liabilities increased by the inclusion of lease obligations, and, because of the permissiveness of the language, it seems highly unlikely that the number of lease arrangements reported as liabilities will be significantly increased as a result of the Board's opinion.

As was the case with accounting for the investment credit, the solution to account-

\footnotetext{
${ }^{32} \mathrm{~J}$. Accountancy, March 1964, p. 9.

${ }^{33}$ For example, Safeway Stores, Inc., rg64 Ann. Rep.; Kern County Land Co., Ig64 AnN. Rep.

34 John H. Myers, Reporting of Leases in Financial Statements ch. 3 (AICPA Accounting Research Study No. 4, I962).
} 
ing for leases calls for consideration of the fundamental concepts of income, assets, and liabilities. Unlike the investment credit, however, there was no urgent need for an APB opinion on leases, especially if the opinion was to be substantially the same as existing pronouncements and if it was merely to accord with the virtually uniform extant practice. The Accounting Principles Board was created in part to correct a serious deficiency in the operations of the Committee on Accounting Procedure it replaced. The Charter Rules explicitly provided that initially the APB would focus on the establishment of postulates and principles "to which each new release shall be related." In the case of the investment credit, the reasons for deviating from that plan were clear and inescapable; in the case of leases, it would appear that the Board acted in unnecessary conflict with the concept under which it was created.

\section{The Recent Opinion on the Status of Accounting Research Bulletins}

Unfortunately, the decision to require disclosure of departures from Board opinions that was adopted as a result of the investment credit situation caused new problems for the Board. The Council action specified that no distinction was to be made between APB opinions and the older Accounting Research Bulletins. It stated explicitly that the Board should review those Bulletins prior to December $3 \mathrm{I}$, $\mathrm{x} 965$, in order to revise or withdraw any that were deemed to be inappropriate. ${ }^{35}$ Thus the Board was faced once again with urgent demands for decisions when the framework for those decisions had not yet been established.

Presumably because of the time pressure, the Board undertook this task with the avowed purpose of recognizing as acceptable those accounting practices then in use which were in conflict with existing Bulletins. The resulting Opinion No. $6^{35 a}$ can only be characterized as adding to the alternatives and inconsistencies that had previously been considered acceptable. For example, in 1939, in 1942, and in 1953, the Committee on Accounting Procedure had considered three methods of accounting for any unamortized discount, issue cost, and redemption premium on bonds that were refunded; one method was designated preferable, another was considered acceptable, and the third was labeled unacceptable. ${ }^{36}$ Opinion No. 6 eliminates the unacceptable designation, embracing all three methods-hence, virtually all possible methods-as acceptable. The choice of methods is not dictated by or dependent upon peculiar operating conditions or peculiar conditions surrounding the refunding transaction; any of the three methods is acceptable for the typical refunding transaction.

\footnotetext{
${ }^{35}$ AICPA, Disclosure of Departures from Opinions of Accounting Principles Board I 7 (Special Bull., I964).

${ }^{35 a}$ Accounting Principles Board, aicPa, Status of Accounting Research Bulletins (Opinion No. 6,1965$)$.

${ }^{38}$ Committees on Accounting Procedure and Accounting Terminology, AicPa, Accountino Research and Terminology Bulletins ch. I5 (final ed. 196r).
} 
The Legal Experience With UNIFormity

In connection with the problem of uniformity in accounting, appeals are often taken to the example of the law, in particular to the example of the common law. ${ }^{37}$ The appellants seem to derive from this analogy support for a reluctance to push towards uniformity. These cannot be taken as suggestions that accounting institutions proceed as the common law does by furnishing answers to one case at a time, to specific past factual problems; all accounting progress to date has been through attempts to lay down rules to cover groups of future cases, an effort more nearly resembling the legal process of codification. As references to the legal process in a single state or other jurisdiction, these analogies seem to go awry in that they overlook the fact that in any one given jurisdiction only one rule exists at any one time. Even though it develops its law by a cautious case-by-case approach, the Supreme Court of Nebraska, for example, does establish a precedent on a given point. That precedent is, until the same court (or the legislature) changes it, the binding authority in Nebraska. There is no fair analogy between such a situation and that which prevails in the accounting profession when two or more alternative solutions have substantial support among members of the profession. If anything, the latter resembles the state of affairs that prevails when private parties are following divergent practices and no court has yet declared that any of them are law, i.e., before the common law process has started to function at all. ${ }^{38}$ In both situations, co-equal decision-makers (not, incidentally, disinterested parties) are establishing patterns that in the same territory have equal standing. This analysis suggests the further idea that there is a more helpful legal analogy, the problem of ending the diversity that exists when several state systems establish different rules, each valid within their respective realms.

The problem of diversity of laws in this sense is one that has been long recognized by jurists. Two avenues of approach have traditionally been used by the courts and lawmakers in seeking to alleviate the problem of interjurisdictional diversity. One is to delimit the competences of the various jurisdictions so that all jurisdictions recognize one of them as having the exclusive right to regulate a given transaction, those with a lesser interest in the transaction giving way to the one with the closest

\footnotetext{
${ }^{37}$ E.g., Savoie, Accounting Improvement: How Fast, How Far?, Harv. Bus. Rev., July-Aug. I963, p. I44; note also the negative comments on such analogies in REED $K$. STOREy, The SEARCH FOR ACcounting Principies 64 (I964).

${ }^{8 B}$ Private custom plays less of a role in forming law than it once did, but the courts still draw on custom where the law is otherwise incomplete. For example, it can be used to clarify the meaning of contracts or to set the standard of reasonable conduct in tort cases. However, custom is subordinate to law and a court can reject a custom as "too slack," as did Judge Learned Hand in The T. J. Hooper, 6o F.2d 737 (2d Cir. 1932), when he found that coastal ships should carry wireless sets even though many did not. Accounting practices are from a judicial point of view custom $i$ in this sense, though most judges feel more confident in revising maritime practices than auditing procedures. On custom generally, see Henry Hart \& Albert Sacks, The Legal Process: Basic Problems in the Making and Application of LaW 427-57 (tent. ed. I958).
} 
relationship. This lies within the field known as conflict of laws or private international law. The other approach is to make the laws of the various jurisdictions uniform so that it will not matter which of them is applied. The law has by now accumulated a fair degree of experience, and some wisdom, about this process which may suggest some analogies for the accounting situation. At the risk of restating material much of which is obvious to the lawyer-reader, we shall briefly summarize this experience. ${ }^{39}$

The process of creating legal uniformity can take place either at the interstate or at the international level. As between the states of a federal system the problem is modified by the fact that there exists some power at the national level to impose uniform rules. Our Supreme Court, for one, can in some areas create uniformity where none previously existed. For example, after all the states but Georgia had come around to the idea that a person on trial for a crime should be allowed to testify under oath and with the assistance of counsel, the Supreme Court held that Georgia denied due process when it clung in solitary splendor to a different rule. ${ }^{40}$ Congress may also step in to create a uniform rule, as it is now considering doing in relation to taxes on interstate sales of goods. ${ }^{41}$

Where no federal rule has been adopted, the states can, by common action, achieve uniformity. Much informal imitation by one state of others has taken place and some uniformity is achieved by the work of private groupings, but today much of the work of standardization is conducted through the National Conference of Commissioners on Uniform State Laws, which first met in $1892 .{ }^{42}$ This body, composed of appointed representatives from each of the states, meets regularly and maintains a drafting and research staff. Its work is reviewed by the House of Delegates of the American Bar Association and ultimately results in recommendations to the state legislatures. These have achieved widely varying degrees of

${ }^{30}$ See Symposium, Unification of Law, 30 Law \& Contemp. Prob. 231 (1965).

to See Ferguson v. Georgia, 365 U.S. 570 (196r).

11 The House Committee studying the problems created by diversity in state tax systems has issued a report (H.R. REP. No. 952, 89th Cong., Ist Sess. (1965)) with its conclusions in part VI. "A major feature of the Committee's recommendations is the establishment of broad areas of uniformity." Id. at 1202. The Report notes that under the present system, "faced with diversity in Statc laws, taxpayers often impose their own brand of uniformity" (id. at r125) by not following meticulously the divergent state reporting requirements.

${ }^{42}$ The history and procedures of the National Conference of Commissioners on Uniform State Laws are discussed in Armstrong, Toward the Betterment of the Law-The Work of the National Conference of Commissioners on Uniform State Laws, Student Lawyer, April 1958, p. 20 (by the Vice-President of the Conference); Day, The National Conference of Commissioners on Uniform State Latus, 8 U. FLA. L. Rev. 276 (I955); Dunham, A History of the National Conference of Commissioners on Uniform State Laws, 30 Law \& Contemp. ProB. 233 (1965). The impetus for the founding of the Conference came from the American Bar Association, one of whose objectives has always been "to promote ... uniformity of legislation throughout the nation." Bodies similar to the National Conference have been formed by state insurance commissioners, attorneys general and others. For a study of trade association activities seeking uniformity, both as to contractual rules and cost accounting practices, with warnings about the antitrust implications thereof, see George P. Lamb \& Sumner S. KitTelle, Trade Association LAW and Practice chs. 5, 6 (1956). 
success, ranging from the unanimous adoption of the Negotiable Instruments Law to proposals adopted by no state or a mere handful of them.

In their endeavors, the Commissioners have a powerful ally in the American Law Institute. $^{43}$ The ALI represents the closest analogy within the legal profession to the APB within the accounting profession. It is a purely private body, financed through private funds and managed by private individuals; this point is, incidentally, not always understood, particularly in foreign countries. It has produced essentially two kinds of documentation. Its restatements are attempts to capture common law areas in summary form. While they are supposed to "restate," i.e., recapitulate rules upon which the courts have reached agreement, there is no doubt but that they do state rules for questions which the courts have not yet had occasion to answer and that they even take it on themselves, in the guise of stating a consensus of views, to resolve conflicts among the cases in favor of what they regard as "the better" rule. The restatements are in a sense addressed to the courts; their practical effect is largely felt through the adoption of restatement views by the judiciary as being the considered views of a reliable and dispassionate group.

The other documents produced by the Institute are drafts of model legislation, most conspicuously the Model Penal Code. ${ }^{44}$ These quite clearly select among existing state variants and even propose improvements on the law existing in any state. Model legislation is aimed at state legislatures in the hope that they will be attracted by an example both modern and, at least in intention, uniform. Both of these types of drafts are originally prepared by reporters, usually law school teachers of the topic in question, aided by a staff of assistant reporters, and checked and guided by a panel of advisers drawn from the judiciary and the bar. Before becoming final they are debated by the Council and the Institute as a whole, thus representing at the end the composite judgment of a sampling of all segments of the profession. Meanwhile, these drafts achieve considerable circulation, involving sometimes criticism in professional journals. This procedure, incidentally, is in many ways similar to that established for the APB.

Some legislation, particularly the Uniform Commercial Code, represents the efforts of both the Commissioners and the Law Institute. The long-drawn-out history of the Code's gradual acceptance by the states shows that even this powerful sponsorship may find it hard to overcome particularistic obstacles on the road to uniformity. ${ }^{45}$

On the international level we find more legal diversity and weaker agencies for

\footnotetext{
${ }^{43}$ For an authoritative discussion of the ALI, see Herbert F. Goodrich \& Paul A. Wolkin, The Story of the AMrerican Law Institute, I923-196I (I964).

“Model Penal Code (Official Draft, 1962); see Sympositum on the Model Penal Code, 63 Colum. L. REv. 589 ( 1963 ).

${ }^{45}$ See Braucher, The Legislative History of the Uniform Commercial Code, 58 CoLum. L. Rev. 798 (1958); Malcolm, The Uniform Commercial Code in the United States, I2 INT'L \& CoMr. L.Q. 226 $(1963)$.
} 
combating it. ${ }^{46}$ Diversity characterizes not only rules that affect relationships between states (public international law) but rules that affect relationships between private parties, such as commercial law. A difference of rules can only be eliminated by the consent of the nations involved. Legislation and common law are territorially limited. Treaties bind only countries that are parties to them. The theory indicates that custom, to become binding international law, must have been universally recognized, or nearly so. International tribunals have not felt they had the power to disapprove practices that had any significant national support. ${ }^{47}$ Thus international life is poor in institutions that can, like our federal ones, bring a dissident minority into line.

Greater difficulties also beset voluntary international agreements. They start with the fact that the participants know that there is little or no reserve force to make them agree if voluntary negotiations fail. They continue with such factors as linguistic diversity, radical diversity in legal traditions, institutions, and methods of analysis, sharply different ideological attitudes towards problems, and radically different actual economic and social circumstances.

Thus it is hardly surprising that the process of codifying uniform rules has made slow progress on the international front, particularly in areas where the interests of the negotiating governments are directly concerned. What has been done has been the product of long negotiations based on long preparatory work. Among the agencies active in the field are the United Nations' International Law Commission, the Hague Conference of Private International Law, the International Institute for the Unification of Private Law, the International Law Association, and a number of other bodies concerned with particular branches of the law. ${ }^{48}$ Some of the most successful efforts at introducing more uniformity into international life have been those of private bodies such as the International Chamber of Commerce and various industry groupings; such arrangements as the Uniform Customs and Practice for Commercial Documentary Credits can, by becoming parts of private contracts or prevailing custom or the basis for national legislation, produce legal as well as commercial uniformity. Not surprisingly, efforts at harmonization seem to have the best chance of making progress when they involve a smaller group of nations having closer common ties rather than the entire international community. The Anglo-American countries, South America, and the European Six are examples of such groupings.

\footnotetext{
${ }^{6}$ On uniformity in laws affecting private parties, see Symposium, Unification of Law, 30 Law \& Contemp. Prob. 23I (1965); Symposium, Current Legal Problems and Possibilities of Co-ordinating Legal Systems to Facilitate International Intercourse, 9 AM. J. CoMp. L. 344 (1960).

"7 For a perhaps extreme position as to the requirement of unanimity for a customary norm, see Tunkin, Remarks on the Juridical Nature of Customary Norms of International Law, 49 Calip. L. REv. 419 ( $196 \mathrm{r}$ ). A case frequently referred to as setting high requirements for the finding of any norm restricting sovereign states is the case of the S.S. "Lotus," P.C.I.J., ser. A, No. ro (1927).

${ }^{48} \mathrm{See}$ sources cited note 46 stipra. On the work of the International Law Commission on public international law, see Herbert Briggs, The International Law Commission (1965).
} 


\section{IV}

\section{Conclusions}

In considering the comparability of the legal experience as to uniformity with that of the accounting profession one must bear in mind a number of differences. These can be grouped under the headings of differences in the purposes of uniformity, of differences in extraprofessional factors, of differences in professional structure, and finally of institutional differences.

First, as to the purposes of uniformity, one should recognize that lawyers and accountants seek uniformity for divergent reasons. The question of lack of comparability, in the sense in which accountants use it, is of little moment in the law; courts and lawyers are not particularly interested in fostering any practice analogous to that of comparing financial statements to determine relative profitability. They are concerned with the more direct effects of clashing legal rules that arise because these rules either make it unclear what a party is directed to do or subject a party to the risk that he will be directed to do things that, when taken together, render his course of conduct burdensome, impractical, or impossible. The disadvantages caused by lack of uniformity in law must be weighed against its possible advantages, such as the ability to adapt to local variations in circumstance and the creation of competing experiments that may point the way to the best alternative. Variation in accounting may also have advantages, where there are in fact variations between groups of concerns, in particular between industries. Any responsible advocate of increased accounting uniformity would concede that one could not force an independent oil producer and a retail store into a common accounting mold. He would be skeptical, however, of the proposition that the differences between the two are such as to call for their using different ways of reflecting their use of the investment credit or of handling unamortized bond expense, matters which do not affect their internal operations but solely their outside reporting. ${ }^{49}$ The experiment factor is probably of less importance in the accounting area since it is more difficult to conceive of ways in which actual experience would prove or disprove the efficacy of divergent accounting methods in fairly representing the situation of firms.

The extraprofessional forces that bear on the two processes are different. The legal profession's own most analogous institution for creating uniformity and progress, the American Law Institute, must, to be effective, convince either the judiciary or the legislatures of the wisdom of its rule. These bodies clearly have the primary and ultimate responsibility for the creation of a satisfactory body of law, including one that is uniform where uniformity is important. It follows that professional bodies such as the ALI are freer to choose those areas of the law that they propose to work upon and are less likely to be called upon to respond to emergency stimuli. While in both cases, the pronouncements of the professional

\footnotetext{
${ }^{40}$ See pp. 714-16, 7r8 supra.
} 
body are not binding, those of the APB have a greater immediate effect, particularly since the establishment of the requirement that departures from them be footnoted. ${ }^{50}$ While the SEC possesses in its important corner of the field the power to lay down rules, it has not been active in its exercise. ${ }^{51}$ This leaves the APB to bear the brunt of the conflict over new and current problems, in a way that its legal counterparts do not. There is, of course, always the possibility that, if the APB does not succeed in its mission, the SEC will become more active, a possibility that perhaps constitutes the strongest lever in the hands of the Board.

The client plays a somewhat different role in the two processes. In the accounting world he initiates the financial statement, and his vagaries can only be repressed if his accountant is willing and able to tell him that his solution is beyond the pale of generally accepted accounting practice. If he is able to persist in his practice, that persistence helps to indicate that his variation is not unacceptable. The lawyer's client may, people being what they are, not do what he is told the law tells him to do. Meanwhile, the client's practices do not usually contribute to establishing the legality of what he does..$^{52}$ It is perhaps significant that some lawyers' clients have a strong interest in uniformity. A finance company doing an interstate business may find it so convenient and economical to have a uniform set of rules that it would be willing to accept some rather distasteful rules as part of the price. Private trade associations may even, as we have seen, proceed on their own initiative towards uniformity. ${ }^{53}$ Only very rarely would an accountant's client not find it convenient to be able to follow its own preferred accounting technique, if it chose to do so, regardless of what others did. Generally only investors and their investment advisers feel the inconvenience of the resulting lack of parallelism. ${ }^{54}$

The intraprofessional environments of the ALI and APB also differ. One has the impression that in general there is more of a cleft between the academic and the practitioner in the accounting than in the legal institution. While some issues will bring out a clash between the academicians and the bar-conspicuously, the one between law teachers and prosecutors over criminal prearraignment proceedings-there is not generally a vehement feeling by legal practitioners that the teachers do not understand the "real problems." The accounting profession seems to have suffered more from such clefts; witness the separate endeavors of the academic organization, the American Accounting Association, to develop principles. ${ }^{\text {t5 }}$ Rela-

\footnotetext{
${ }^{50}$ See pp. 708-og supra.

51 For an evaluation of the SEC's past use of this power and the likelihood of extended use in the future, see Anthony, Showdown on Accounting Principles, Harv. Bus. Rev., May-June I963, p. 99 . Sce also Pines, The Securities and Exchange Commission and Accounting Principles, infra, pp. 727-51.

${ }^{62}$ But see note $3^{8}$ supra for the effect of practice on law.

Es See LAMB \& KITTELLE, op. cit. supra note 42 , chs. $5,6$.

"t Of course, where lack of uniformity is caused by the accounting requirements of different agencies, affected businesses are quick to feel its inconvenience. See note $4 \mathrm{I}$ supro and such cases as Appalachian Power Co. v. FPC, 328 F.2d 237, 246-52 (4th Cir.), cert. denied, 379 U.S. 829 (I954).

${ }^{56}$ See STOREY, op. cit. supra note 37 , at 5I-52.
} 
tionships between groups of practitioners also differ in the two institutions. Lawyers at times bring to their professional work the attitudes of their clients-sometimes in very general terms, as when defense-oriented lawyers consider procedural matters, and sometimes in more particular terms, as when bank-connected lawyers consider the negotiable instrument provisions of the Uniform Commercial Code. This sort of position is apt to be subject to "horse-trading," to the acceptance of some disliked provisions as the price of important concessions. Divisions within the accounting profession have tended to be of a different type. There is a clear-cut confrontation between uniformity and flexibility champions on a consistent and rather dogmatic basis. It is difficult to effect compromises in such a situation, and particularly so when, as with the investment credit, only one issue at a time is presented so that there is little room for maneuver.

One is led to suspect that lawyers approach problems of uniformity in a somewhat different spirit than do accountants. By the very nature of their training and work, they are rather more habituated to disputes and accustomed to the means whereby they may be settled. Each recognizes that he and his client will not always prevail and that decisions fairly arrived at by the courts, legislatures, or other agencies within the authority given them must be accepted even if distasteful. They, furthermore, see that it is often in the law preferable to have a fixed and uniform rule, even if slightly arbitrary in nature, than to have it nicely adjusted to their clients' own individual predilections. Accountants, on the other hand, seem less willing to say, for example, that the different ways of treating the investment credit are all defensible and not irreconcilable with basic theory but that they will accept a decision that selects one of them as preferable to lack of agreement. Thus one may expect a somewhat greater tendency in the legal profession to acquiesce in the recommendations of its bodies charged with the function of creating uniformity.

Another differentiation between the environments within which legal and accounting movements to diminish diversity must operate is to be found in the varying degrees of systematic generalization that prevails in the two fields. Legal scholars have long worked at erecting a systematic structure of rules descending from higher levels of abstraction to more specific terms. Courts, practitioners, and codifiers have contributed to the construction of this edifice and have tended to work within them. Modern lawyers have been trained to believe that "abstract principles do not decide concrete cases," but surely it helps narrow and focus debate on particular issues to have a generally agreed upon framework within which to conduct it. Accounting has had rather less of such generalizing work, and such systematizing as has been done by theorists has had less widespread recognition. Accountants can differ as to how many decisions on accounting issues would be controlled by common acceptance of general postulates or principles. ${ }^{56}$ Some choices

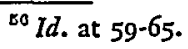


between competing methods clearly will not be so controlled, and the selection made will have to be somewhat arbitrary in nature. However, absence of such consensus has certainly made more difficult the kind of dialogue from which agreement on specifics might emerge.

Differences are thus apparent between the environments within which the APB and, for example, the ALI operate. The pressures and demands on the former are considerably greater, and the obstacles to its accomplishing its mission are more formidable. One cannot wholly attribute to weaknesses within the APB the problems it has been encountering. It is, however, appropriate to ask whether there have been internal, procedural factors at work that have hampered it in its efforts. First, one would note that the APB has, in its most crucial affair, the investment credit melee, been hindered by a need for haste that made it impossible to secure the full and deliberate proceedings, ordinarily called for by its own rules, that might have reassured doubters about the rightness of the outcome. ${ }^{67}$ Second, it appears that the presentation of narrow, isolated issues such as the investment credit makes it even harder to achieve agreement because of the lack of opportunity for reciprocal concessions by opposition parties (assuming that they are willing to make them) and because of the lack of relationship to general principles. Third, the situation of the APB has been such that it has in some cases had to respond to questions thrust upon it by events. The ALI has been able to select topics that are not only generalized but that have shown signs of ripening to the point where uniformity is achievable. Whereas the ALI can gain acceptance from the fact that its labors usually represent the most thorough and systematic available analysis of broad fields, the APB has not been able to derive strength for its particular opinions from any of the endeavors it has undertaken to study fundamental postulates and principles. The latter studies were set aside to "ripen" and, absent the imprimatur of the $\mathrm{APB}$, have not even become starting points for reasoning about accounting. ${ }^{68}$

The legal experience taken as a whole indicates that uniformity does not grow of itself and that the increasing complexity of commercial life tends to spawn new variations of activity for which new legal, and accounting, responses develop. Even to maintain a given level of uniformity calls for conscious effort, exerted through institutions appropriately designed to that end. Those institutions must have the qualities indicated above, representativeness of the various groups, the capacity for unhurried deliberation, and the respect of the profession. Finally, they must have a capacity to make decisions with a certain element of arbitrariness in areas where neither experience nor logic will ever definitively dispose of some of the alternative solutions supported by some parties. Viewed in such a context, the APB can be seen to be confronted with formidable obstacles and to contain internal weakness. The prospects for speedy movement towards uniformity do not seem promising.

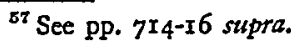

${ }^{\text {c8 }}$ See p. 712 supra.
} 